\title{
Biological and Cultural Anthropology of a Changing Tropical Forest: A Fruitful Collaboration across Subfields
}

\begin{abstract}
In this article, we integrate approaches from biological and cultural anthropology to describe changing relationships between humans and animals in the Dzanga-Ndoki Park and Dzanga-Sangha Dense Forest Reserve (RDS), Central African Republic (CAR). Recent decades have seen a rapid proliferation of human activities, with striking tensions between logging and conservation economies. Our data suggest that certain animals and humans initially adapted successfully to these forest uses, and that local residents have crafted culturally rich new ways of living in the forest. However, our longitudinal data indicate animal declines and expanding frontiers of increasingly intensive human use. These trends are altering previous territorial arrangements and coming to undermine today's remarkably rich spectrum of human-animal encounters there. Our combined approach offers an alternative to increasingly distinct method and theory between anthropology's subfields. We sketch a research agenda for integrated anthropological attention to environmental change, especially to transformations in human-animal interactions and entanglements. [Keywords: ethnography, primatology, Africa, social change, environmental anthropology]
\end{abstract}

\section{BIOLOGICAL AND CULTURAL ANTHROPOLOGY IN AN AFRICAN FOREST SITE}

The collaborative research we describe here exemplifies the potential of place-based work across anthropology's subfields for improved understandings of complex social and ecological systems. This research combines information and interpretation from biological and cultural anthropology, to better understand the interactions between human and nonhuman primates in the Dzanga-Ndoki Park and DzangaSangha Dense Forest Reserve (RDS), Central African Republic (CAR; see Figure 1$).{ }^{1}$ We designed this as a small-scale study in 1997 to enhance our respective ongoing research projects regarding the consequences of displacement and transformation of traditional hunting and gathering in favor of new forms of forest use, primarily logging and conservation. Our combined work provides insights into three related aspects of change in these forests: (1) changing human perceptions and uses of the forest, (2) spatially varied human and animal adaptations to habitat change, and (3) a decline in animal densities in the research area. ${ }^{2}$

Our work is rooted in the rhythms of life in forest camps, whether for logging, research, or hunting and gath- ering. Considering our time in such camps since the late 1980s and early 1990s, we note that human life is both materially and ideationally impoverished by animal declines. For example, the animal tales so commonly and powerfully told by our local collaborators in earlier study periods are being replaced by discussions of destructive logging practices and discord between local residents and conservation agents at RDS, and many voice their concerns about prey scarcity.

After considering some of the common origins, divergent practices, and contemporary convergences of biological and cultural anthropology in analyses of environmental change, we briefly historicize a wide array of human-animal encounters across sectors of the RDS. The combined approach of transect work with ethnographic observation and work/life histories enables us to explain increasing human predation on gorillas in the research area. We do so by describing the context of economic activity and human immigration in RDS, along with related social changes which appear to cause local declines of prey populations that are alternatives to gorillas. Our results extend analysis of human-animal interactions from the "snapshot" 


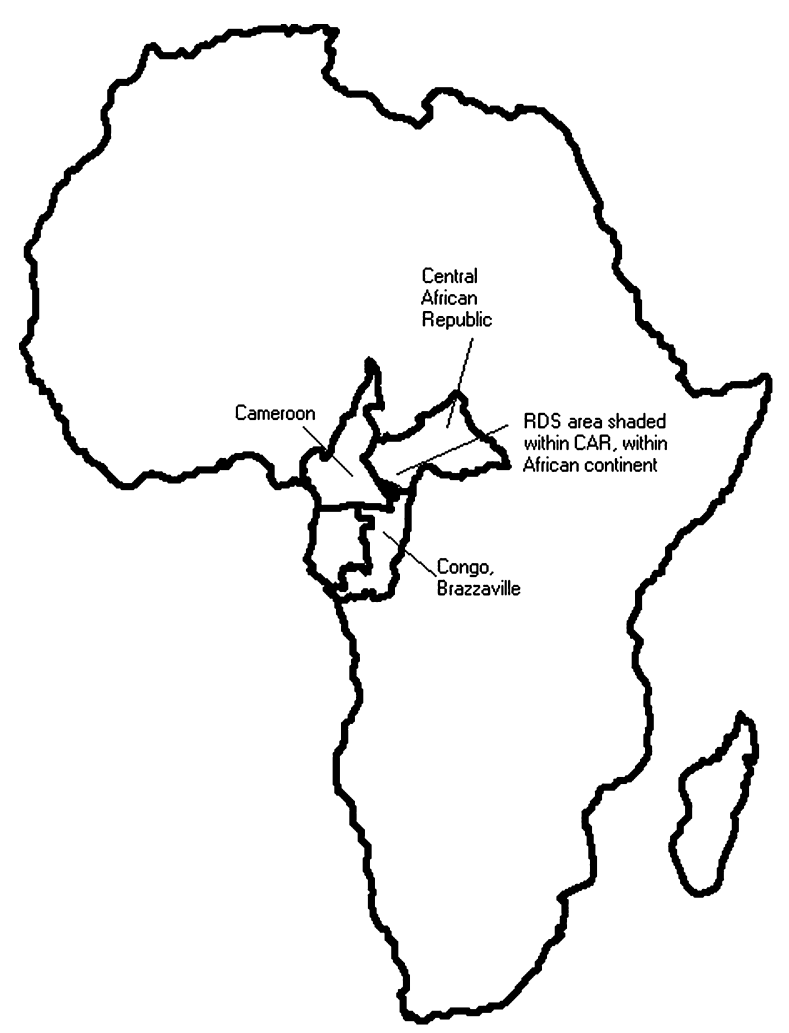

FIGURE 1. Location of Research Area, Dzanga-Sangha National Reserve (RDS), within the Central African Republic (CAR) and within Africa. Map is based on an original hard-sketched map by Stephanie Rupp.

views so often used in forest assessment for exploitation or protection to a rich panorama of regional processes unfolding within competing resource-use regimes.

\section{SUBFIELD HISTORIES AND NEW ENVIRONMENTAL ANTHROPOLOGIES}

Biological and cultural anthropologists, particularly those working in the emerging conservation science field, often share research sites, but only rarely share research "cites." They work within the same institutional contexts and even meet in research camps or work with the same informants, but they are rarely immersed in the same scientific literatures and intellectual or technical debates (Rodman 1999). As conservation becomes increasingly politically charged, they may even occupy opposed camps. Conservationist agendas that embrace the new sciences of environmental management-collaborating with model builders, corporate sponsors, and policy makers-are increasingly interpreted as counter to the interests of indigenous peoples (Brosius 1999; Chapin 2004) or connected to colonial legacies for the understanding and control of the natural world (Sawyer and Agrawal 1997; Spurr 1993).

Working on this project, we found it difficult to recognize and reconcile our respective senses of embedded "advocacy" in our engagements with this field context (for animals against human encroachment, in the case of Remis; for forest-dwelling humans against conservationist and other regional and global actors, for Hardin). These differences sometimes produced serious disagreements about how to proceed. Ultimately, however, such differences were smaller than those that separate us from much conventional popular and technical knowledge about "saving the rain forest." Resource-use management is rapidly being decentralized, empowering local communities to monitor resource use but not necessarily to determine the values ascribed to nature and internalized by individuals (Agrawal 2005). New uses for nature, including transgenics and pharmaceuticals, are spurring intense interest in the ethical, aesthetic, and economic entanglements of humans with nonhumans (Haraway 2003). As demands for expertise increase in these rapidly expanding regimes and economies of nature, the pace of knowledge production hastens. Truly long-term immersion in a set of places and processes-neither for project implementation nor profit realization but, rather, for information gathering-begins to seem a true luxury. It is one we have been fortunate to have shared.

We have assembled an integrative analytical perspective from distinct biological and cultural anthropology literatures that have in common an increasing emphasis on complexity and change. Of course, such an emphasis is not new to our field: Sherwood Washburn's (1951) biological anthropology adaptationist approach ${ }^{3}$ and the cultural Boasian legacy of cultural types or patterns ${ }^{4}$ were both significant departures from the classificatory typologies that dominated anthropology's imperial past. Their work resonated with early human cultural ecology (see Orlove 1980), aptly criticized as somewhat synchronic and analytically inclined toward closed systems (Peet and Watts 1996:4). Such work is nevertheless an important part of intellectual legacies for describing humans as part of global ecosystems, subject to natural as well as historical, cultural, and political forces (see Kottak 1999).

Recent cultural anthropology of hunters and gatherers focuses increasingly on changing ecologies and identities within larger local and regional economies through colonization, migration, state formation, and global trade (Kent 1996; Leacock and Lee 1982; Rival 2002). Contemporary work that thus reinvigorates the classic monographic genre complements more experimental ethnographies of global dynamics of knowledge and power (Tsing 2004) or of the ontological and historical entanglements of humans, animals, and natural elements (Raffles 2002).

Biological anthropologists have begun to address the issue of increasing human incursion and predation on great apes, most of which are projected to go extinct within ten to 20 years (Redmond and Abe 2000; Richard 1981; Strier 1997; Van Schaik et al. 2001). Recent work in primatology analyzes dynamic human-animal relationships in primate conservation (Fuentes and Wolfe 2002; Oates 1999) and in primate and human health (Wallis 1999; Weiss and Wrangham 1999). Such contributions feed anthropology's own debates about its identity as both a critical and a scientific field (Pavelka 2002; Strum and Fedigan 2000). 
In the last decade, there have been calls to action against irreconcilable differences between subfields (Cartmill 1994; Lee 1999). Schisms persist; at the same time, scholars are creating theoretical terrain on which different types of anthropology can meet and even morph into new approaches. Some biological anthropologists have pursued analyses of the gendered nature of science and primate studies (e.g., Fedigan and Strum 1997) or even the role of narrative in models of human evolution (Landau 1991). Conversely, cultural anthropologists are again engaging with ecological frameworks, this time helping to produce them through concepts such as resilience and emergence (Abel and Stepp 2003), rather than merely "borrowing" concepts from an ecological lexicon (see Dove 2001). Analysis of the tropes of contemporary popular cultures with respect to forest conservation also represents a frontier of cultural studies, as it can inform both anthropology and ecology (e.g., Slater 2003).

Perhaps most directly relevant to our work together is the emerging domain of ethnoprimatology (Cormier 2003; Sponsel 1997; Wheatley 1999). In practice, however, few contemporary biological anthropologists or ecologists have joined forces with ethnographers to create biocultural field research programs that capture important trends at smaller scales over time. Our collaboration revealed not only previously undocumented gendered aspects of change in forest use but also species-specific microregional trends in change and the distinct consequences of diverse, overlapping economic activities in a single ecosystem.

The process of designing this study and of integrating and interpreting such diverse data has occurred through several phases. During our graduate training at Yale University, ${ }^{5}$ we availed ourselves of the occasional opportunities for cross-disciplinary social interactions, as well as occasional cross-subfield seminars despite being from very distinct and subfield-specific cohorts. Our mutual advisor, Alison Richard (now of Cambridge University), provided a model for expansive anthropological practice. Although she has published almost exclusively on primate behavioral ecology, she has collaborated with social scientists to create a community conservation project in Madagascar and has built institutional frameworks for interdisciplinary work in conservation and environmental science at Yale.

During the latter phases of our graduate and postgraduate work, we cheerfully collaborated to publish the results from a field-based conference aimed at integrating local expertise with more formal natural and social science perspectives on the western Congo basin (Hardin with Remis 1997). Writing for American Anthropologist, however, we realized that we have each internalized powerful stylistic and substantive concerns from our respective subfields-some of them painfully predictable. Hardin's incessant removal of quantitative data from the manuscript betrayed her lack of basic "numeracy" with respect to ecological monitoring; Remis's lack of patience with complex conceptual expressions betrayed an aversion to anything resembling social theoretical "jargon."
Yet we have come, individually and together, to the sorts of insights that many anthropologists share: Attentive to unpredictable shifts or patterns, our results are sometimes at odds with those produced through more standardized and easily replicable methods; our conclusions are often slow to mature through months if not years of shifting research-and life-in a given field context. Remis, during her initial research, discovered that unlike other gorilla populations, gorillas at RDS frequently nest on bare ground, especially during the dry season (Remis 1993). Thus, single survey methods for estimating gorilla populations that rely on nest counts are not accurate unless viewed against a backdrop of finer-grained longitudinal research. Hardin, having worked primarily on the ethnography and history of river peoples in the region, had assumed that the local hunters and gatherers were rapidly and irrevocably acculturating and sedentarizing. One year, however, she found that most of them had abandoned their homes and settlements near town in favor of seminomadic forest life, a signal of their continued involvement with forest cycles. Remis had long-term data on forest phenology, and so explained that only once every few years does the forest thus fill with flowers (esp. from Dialium species; see Remis 1997). Our discussions of how these fruiting patterns created an exceptionally rich honey season that left logging and conservation managers back in town wondering what to do without many of their workers spurred this forest-based collaborative effort.

\section{RESEARCH IN A CHANGING RAINFOREST}

Generally underrepresented in Africanist and tropical forest-related literatures, the western rim of the Congo basin is remarkable for its abundance of large herbivores and other animals. We consider animals as crucial symbolic and material resources for those humans we study. For Roy Grinker (1994), the pair "human-animal" serves with other oppositions (male-female, insider-outsider, or colonizer-colonized) in socially unequal but economically and ecologically complementary relationships between foragers and farmers in the Ituri forest. For Simha Arom and Jacqueline Thomas (1974), the half-human and half-animal figure of the Mimbo (hunting spirit) among the Gbaaka, farmers in CAR, is a cipher for the powerful alterity of those forest dwellers on whose knowledge they depended during their migration into the forest centuries ago.

Hunters and gatherers in the region of southwestern CAR call themselves BaAka. They are often featured in tourism- and conservation-related publicity. Despite our reservations about the overwhelming ethnographic and tourist attention this group has historically received (as opposed to village-based farmers, known locally as Bilo), we focus here on the BaAka. They have the most specialized knowledge about the forest and are among the most directly dependent on it for food and income. They are also largely excluded from formal education and opportunities for economic development.

Among the animal species on which we collected data, we focus primarily on gorillas. Donna Haraway (1989) 
argues that nonhuman primates occupy a liminal place in the cultural construction of boundaries between humans and nature, and certainly this is true for most inhabitants of the region in which we are working. Jerome Lewis (2002) notes the particular importance of gorillas and chimpanzees in ethnic stereotyping among residents of northern CongoBrazzaville. Michelle Kisliuk (1998) catalogs the ambiguous role of Sumbu the chimpanzee in BaAka repertoires of song and dance in southern CAR. Apes are also fascinating to tourists as well as the main targets of growing ecotourism and research efforts at RDS (Blom et al. 2004a). These efforts aim to create economies that will conserve them despite their slow life history patterns, which increase their vulnerability to hunters (Robinson et al. 1997).

We focus on forest change with respect to two activities: conservation and logging. Logging creates road networks that facilitate uncontrolled hunting; the resulting forest fragmentation also alters species composition (Laurance and Bierregaard 1997; Malcolm and Ray 2000). Andrew J. Noss (1998) notes that many of these factors in the RDS have fostered rapid proliferation of inexpensive but wasteful wire snare hunting. The effects of these changes on wildlife, especially primates, are often not initially detectable (Chapman and Lambert 2000). Conservation, in attempting to prevent such damaging practices, also introduces new relationships that favor more educated residents, primarily men, in access to core protected areas, which are reserved for monitoring, leisure, and research.

Biological and cultural anthropological research has developed and proceeded separately in the RDS region: the former through work in genetics and socioecology (Bradley et al. 2004; Carroll 1997; Cavalli-Sforza 1986; Doran and McNeilage 1998); the latter largely through the cultural ecology of hunters and gatherers (Bahuchet 1985; Demesse 1980; Hewlett 1991; Joiris 1996; Sato 1992). Studies that analyze changing relationships between humans and nonhuman primates remain scarce (save Kano and Asato 1994). There is thus an urgent need for more crosscutting descriptive work. Our evidence includes the following: (1) ethnographic literature on BaAka hunting and gathering, (2) our ethnography of hunting camps and town life, (3) colonial and contemporary archives, (4) line-transect data from 1997 and 2002, (5) previous wildlife census data for the study area in 1985, and (6) our long-term data on forest phenology and gorilla socioecology. ${ }^{6}$

\section{FOREST USE IN A TWO-COMPANY TOWN}

In 1971, the Bayanga area was attributed as a timber concession to a Yugoslavian parastatal logging company. Until 1982, the area was selectively logged (typically Entandrophragma species were logged at one to two stems per ha; see Figure 2). Slovenia created the modern infrastructure of a "company town" in Bayanga (see Figure 3). They produced forest fragmentation effects, including altered species composition of small mammals, primarily along a grid network of roads that are still used today (Malcolm and Ray 2000).
Since 1990, the study region has been officially designated a forest reserve (RDS) with multiple subsectors, each of which has its own set of permitted and prohibited activities. Currently the CAR government, in conjunction with the WWF and the GTZ, ${ }^{7}$ manages the protected area. In principle, reserve policy favors hunting-and-gathering lifestyles for forest residents; in practice it constrains their use of the forest for hunting and gathering while providing some alternative income through ecotourism.

But income sources have multiplied beyond their control, and Bayanga has become a two-company town. By 1995, despite efforts to create a biodiversity-based local economy, logging resumed. Sylvicole de Bayanga (S.A.) employed up to 400 people at a time and concentrated prospecting and cutting to the south and west of the town of Bayanga. In 1996, prospecting began in the Yandoumbé sector of the buffer zone, where our study in 1997 reveals some of the most intense and varied forest use in the RDS. In 2001, a new company took over logging operations, replacing Sylvicole, and began harvesting in the buffer zone up to the park borders, as shown by the lightly dotted areas in Figure 2.

Bayanga's population has thus risen, largely through in-migration, from about 3,000 (Loudiyi 1995) to approximately 5,000 in 2001 (WWF n.d.). Although fluctuating according to economic activity in the area, human population was projected at around 10,000 by 2004 . This creates expanding infrastructures (see recent roads in Figure 3 ) and intensifying exploitation of surrounding forest resources. Currently flanked by active logging and conservation complexes, the center of Bayanga is filled with families who make ends meet by combining work in one of these two industries with hunting, gathering, fishing, or farming.

An overview of nonhuman populations in the RDS area would produce a converse trend from that among humans: From early estimates of nearly 1.2 elephants and 1.8 gorillas per square kilometer (Carroll n.d.; Fay 1989), we see that these animals have become scarce in those areas heavily used by humans. In the early 1990s, Bayangans had to avoid elephants and hippos if walking at night, even within town. Young men harvesting palm wine often found DeBrazza's monkeys (Cercopithecus neglectus) foraging in the treetops where they had left their jugs overnight. Groups of children washing at the town's riverbanks regularly glimpsed a lone juvenile gorilla that frequented the opposite bank. Such encounters with animals around town are now almost entirely a thing of the past.

\section{STUDY STRUCTURE, METHODS, AND RESULTS: A CONTINUUM OF CHANGE}

Mixed human exploitation at RDS leans toward logging in the Yandoumbé sector, which is located in a buffer zone, and toward a conservation economy of research and tourism in the Messapoula sector, which includes part of the core protected area. A third study sector, Kongana, straddles the border between core and buffer zones and represents combined forest uses (see Figure 2). Each area 


\section{Study Sector Map With Conservation Zones and Approximate Logging Chronology}

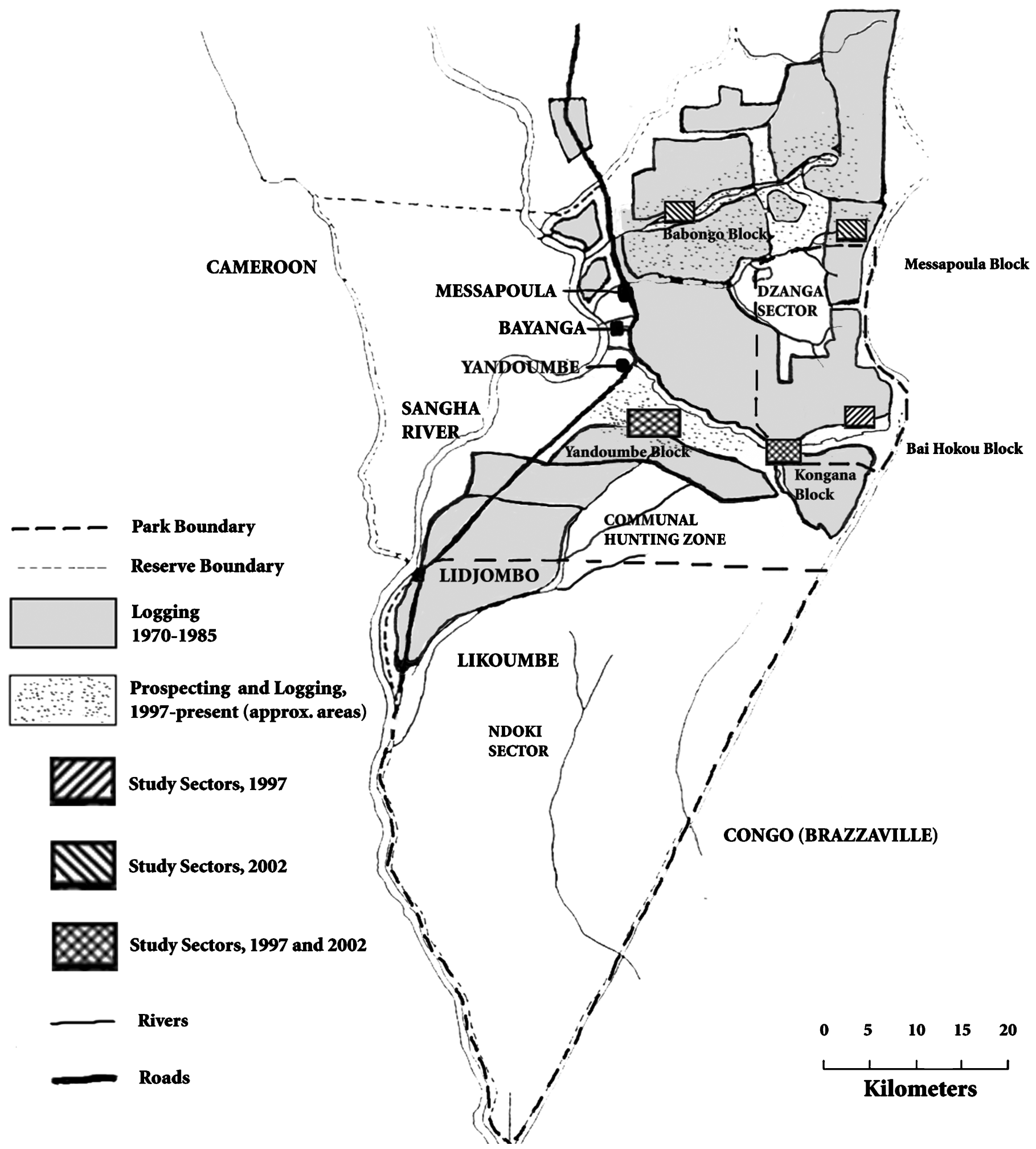

FIGURE 2. Specific study sectors and conservation zones, with schematic history of logging. Adapted from World Wildlife Fund (WWF) archives, courtesy of Allard Blom, and Slovenia Bois archives, courtesy of A. Kretsinger and Calixte M. Mpago. 


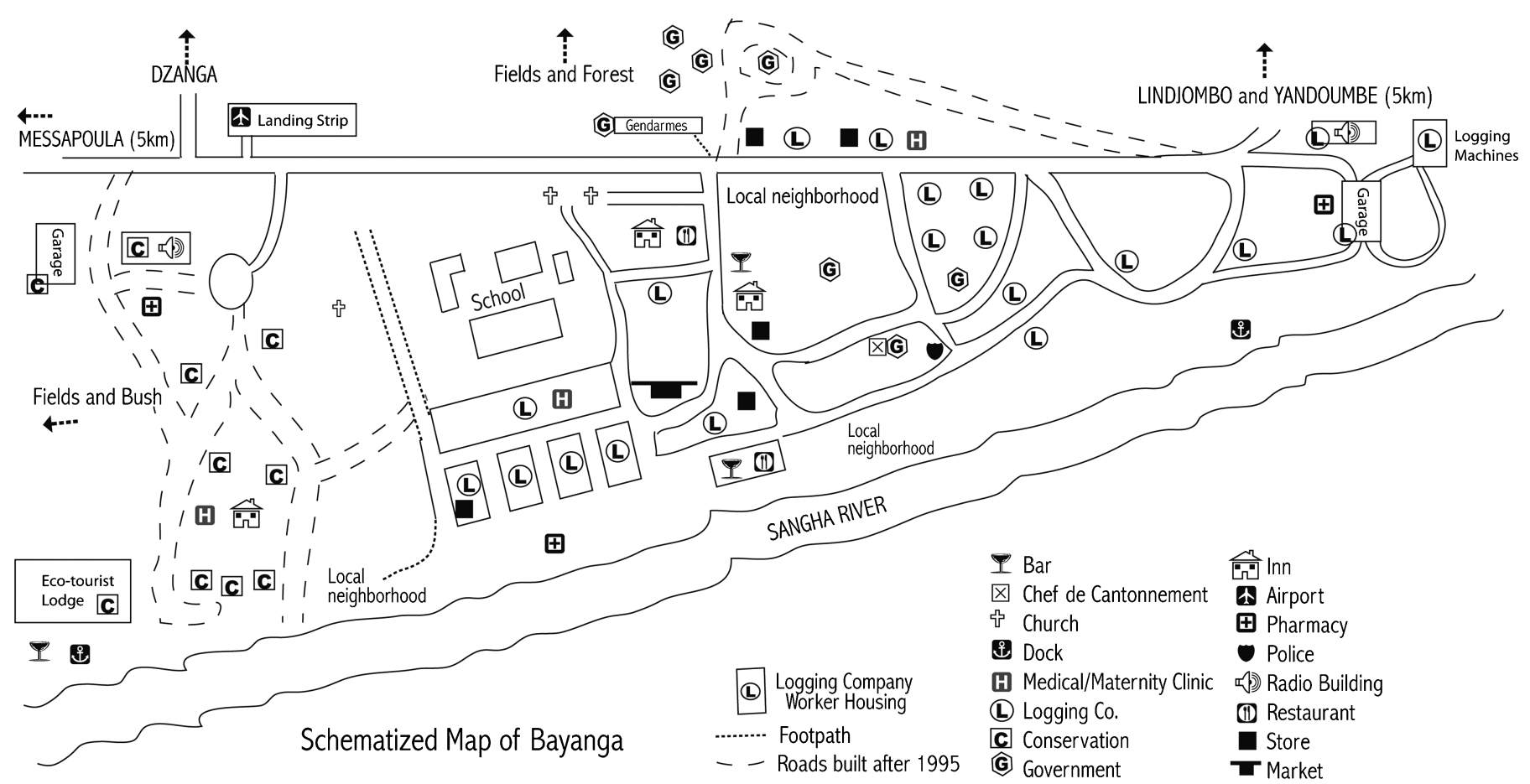

FIGURE 3. Schematized map of the town of Bayanga with locations of logging and conservation infrastructure as well as new roads and buildings in the late 1990s. Adapted from original map by Yon Makino.

was historically, and is still, used by groups of BaAka who maintained distinct territories southeastward of their permanent settlements on Bayanga's main road. Much of the reserve is still thus laced with footpaths, maintained in part by humans but also by elephants, and dotted with camps from which people gather forest products and hunt with traps, nets, and firearms.

Ethnographic methods included census of the camps, collections of migration and work histories, reconstruction of hunting paths and territories, and kinship charts of clans occupying the camps. We also engaged in participantobservation and semistructured interviews, largely in the national language of Sango. Visits during the 1997 study lasted between three and five days per camp, as had previous visits in 1993 and 1995. Hardin also conducted followup interviews with forest camp residents as well as their Bilo trading partners back in the roadside settlements in 1999. In 2002, Remis made three shorter visits over a ten-day period to a large BaAka hunting camp in the vicinity of the transects.

Our methods of wildlife census data collection and analysis were modified from techniques used in previous studies (Tutin and Fernandez 1984; White with Edwards 2000). In 1997 we surveyed 82 kilometers of line-transects in the three sectors, whereas in 2002 we surveyed 100 kilometers at five subsites. Transect work was carried out in one wet and one dry season (1997 and 2002, respectively). Although it is not possible to fully account for seasonal changes in this data set, our comparisons to Richard Carroll's (n.d.) dry season transect surveys permit us to control for the effects of seasonality on elephant and gorilla populations (our primary emphasis, along with heav- ily hunted duikers) and to historicize the trends we describe (see note 2 on further census results).

In the 1997 census, gorilla sign was correlated across sectors inversely with human activity and poaching rates (Remis 2000). In 2002, all wildlife sign was inversely related to human activity at each subsite (Pearson's $r=-.518$, $d f=19, p=.019)$ but was also related to increased logging activity (Pearson's $r=-.547, d f=19, p=.013$ ) and to the percent of forest blocks transected by primary logging roads and skidder trails (Pearson's $r=-.649, d f=19, p=.002$ ). Overall rival economic sectors (logging vs. conservation) have influenced distinct sectors of the reserve (north vs. south; buffer reserve areas vs. core sectors) and determine the particular microregional dynamics of change and decline, which we describe below.

\section{Yandoumbé Sector: Cultural Diversity in a Buffer Zone}

Yandoumbé village illustrates the transnational connections that create forest landscapes in southwestern CAR. North American Louis Sarno founded it in 1991 as a small camp south of Bayanga (see Figures 2 and 3). He hoped to entice BaAka back to "traditional" hunting and gathering from their settlement within Bayanga (Sarno 1993). But "traditional" camp life and "modern" roadside life exist in symbolic contrast and material complement with one another for most BaAka, who move between them at different times of the year for varying lengths of time. ${ }^{8}$ Even as it has grown, Yandoumbé has split into smaller settlements along the road that reflect the continued importance of forest camp social relations and access to the grid of paths running to the southeast through the forest to those camps. 
Each of the new "segments" of Yandoumbé corresponds to the home of a kondja wa lango (or forest camp leader) and his local group of wives and dependents. ${ }^{9}$

Whether or not logging is a positive thing depends on whom one asks. Most of the BaAka hunting camp leaders in the Yandoumbé sector work at least intermittently for logging teams in the area and report earning about 6,000 CFAFs per week (or $\$ 12$, which is slightly more than what they can make from hunting if prey is abundant). During our walks with them, they navigated by the logging road grid cut for prospecting rather than older footpaths. They saw this access, and the availability of cash for manufactured goods, as positive consequences of logging. Women, however, noted that alcohol is a terrible temptation for spending on payday, and hunger or even abuse within households may ensue. Several women we studied had entered the forest to heal their children from crippling parasitic infections contracted in the less-than-sanitary permanent roadside settlements. In the forest, they said, there is more food for their children.

Their comments raise the question of whether logging, and the growing bushmeat trade (discussed in a later section), entail a concomitant decline in knowledge and practices of gathering. Our data suggest that, as with hunting, there are important distinctions depending on the particular type of forest product in question. Honey, for example, is widely valued in regional economies, highly prized within BaAka cultural practice, and cyclically available. The year 1997 was an especially rich honey season, so BaAka remained in small forest camps for weeks on end, celebrating with nights of music, dance, and forms of flirtation strongly associated with honey as a courtship gift from men to women. But Mabanji, a camp leader widely recognized for his ability to gather yams, noted that valuable tree species that produce foods (such as Irvingia gabonensis or Baillonella toxisperma) and those that harbor edible caterpillars (such as Etandophragma cylindricum or Triplochyton scleroxylon) had disappeared because of logging.

Transect data from 1997 in the Yandoumbé forest sector reveal heavier human activity than in other more remote sites studied that year, likely related to prospecting by the local logging company and to the relative proximity to villages (see Table 1). Animal sign was scarce in this sector relative to more distant zones surveyed (Remis 2000). Despite dense human presence, gorillas were actively foraging among the herbaceous growth that follows prospect- ing and logging activity. By our 2002 census, relogging and road building had transformed forest structure (see also Struhsaker 1997); in addition, tree mortality was high. Also by 2002, hunting had increased in the region, no longer restricted to the zone surrounding the villages. Hunters interviewed at that time admitted that they were hunting on both sides of the park boundary in search of scarce prey. The duiker populations had declined dramatically, and elephants were absent. Gorilla nests were rare in the area, suggesting that any ability of gorillas to coexist with humans in this sector, as noted in 1997, was short term. Remains of large-scale smoking racks for elephant meat were common at abandoned hunting camps along transects in this region (See Tables 1 and 2).

Youthful informants shared tales of bloody confrontations between their fathers or grandfathers who were ntuma (masters of the great hunt) yet who avoided taboo prey animals such as chimpanzees (Pan troglodytes) and bongo antelopes (Tragelaphus euryceros). Although they retain a broad hunting knowledge, and many participated in such a hunt once as a rite of passage to adulthood, most such informants cannot claim the expertise that constituted the power of the ntuma for their parents' generation. ${ }^{10}$ Yet hunting and gathering remains culturally-not merely economicallycrucial for these communities. Yandoumbé forest, close to national borders and in constant contact with northern savannas, has long been a meeting ground for varied cultural forces. For instance, during Hardin's 1997 fieldwork in the Yandoumbe sector, most mornings at dawn found the group's older men engaged in BaAka ritual stomping and singing before a net hunt, while others left to check their wire snares nearby. Later in the days of that same stay, the group of men and women hunters carried out a Gbeya language ritual called Ganjia for luck (whether they appropriated both the ritual and the technique of net hunting from their Gbeya-speaking neighbors centuries ago is not known). This vibrant diversity of hunting methods and ritual practices depends on a viable and diverse prey base, which is declining.

\section{Messapoula and Bai Hokou: Professionalization in a Core Protected Area}

At the inception of the national park, BaAka hunting camps were numerous along Bai Hokou, a water-fed clearing, and nearby tributaries (Carroll n.d.). The roadside community

TABLE 1. Wildlife Census Results: Mean Encounter Rate with Animal and Human Sign by Kilometer, in 1997 and 2002 in Three Study Sectors, Dzanga-Sangha Reserve, CAR.

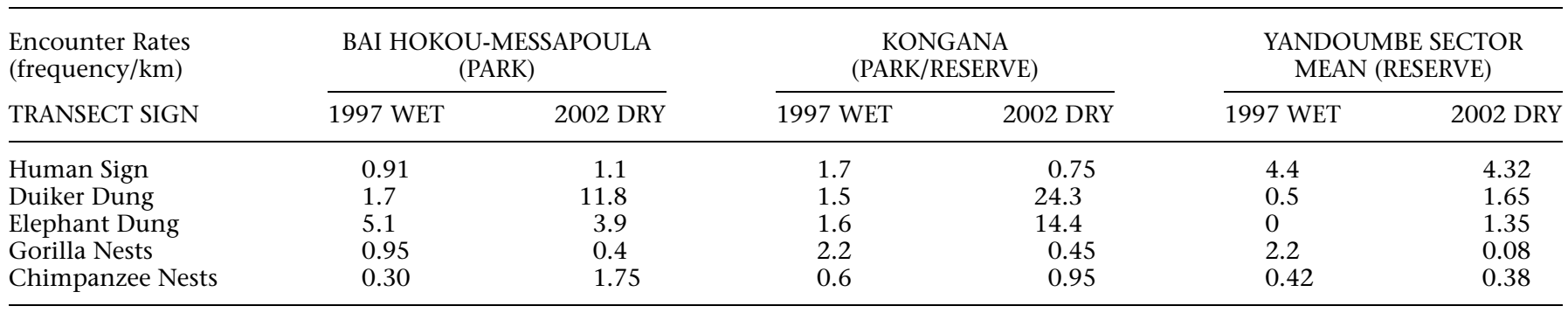


TABLE 2. Mean Encounter Rates of Animal Sign per Kilometer on Transects in Park and Reserve Sites, Dzanga Sangha Reserve, CAR, 2002.

\begin{tabular}{lcccrc}
\hline Animal Sign & $\begin{array}{c}\text { Park } \\
\text { Mean }\end{array}$ & $\begin{array}{c}\text { Reserve } \\
\text { Mean }\end{array}$ & t stat $=$ & $\mathrm{df}=$ & $\mathrm{p}=$ \\
\hline Duiker dung & 18.05 & 1.75 & 5.73 & 7 & 0.001 \\
Elephant dung & 9.15 & 0.95 & 1.91 & 7 & 0.048 \\
Chimpanzee nests & 1.35 & 0.42 & 2.62 & 9 & 0.013 \\
Gorilla nests & 0.43 & 0.07 & 1.72 & 8 & 0.06 \\
Monkey encounter & 9.7 & 6.22 & 3.8 & 11 & 0.002 \\
Human sign & 0.846 & 4.76 & 6.12 & 13 & 0.001 \\
\hline
\end{tabular}

of BaAka that once used this sector for honey or hunting camps is called Messapoula (see Figures 2 and 3). Conservationists had close alliances with Messapoula residents who were the trackers and guides during demarcation of these areas for protection. Yet many BaAka from Messapoula now perceive the creation of the park as a problem for finding adequate game to support hunting and gathering. They maintain a strong but not exclusive hold on employment as guides for research and tourism within the wider reserve area and limit their off-take to species such as tortoises or small-stream fish.

Common research practices in the early 1990s enabled BaAka trackers to move their families into the research camp. This reduced absenteeism that was taking a toll on gorilla tracking - an activity that relies on daily presence and cumulative knowledge about the movements of the animals. It also permitted the BaAka to blend the benefits of forest camp life with nonhunting employment. It provided circles of huts where BaAka personnel would nightly sing and dance for their children, thereby continuing some form of gano, which Jerome Lewis (2002) and Michelle Kisliuk (1998) both describe as an essential practice of knowledge transmission through songs and stories about human encounters with animals (see Figure 4).

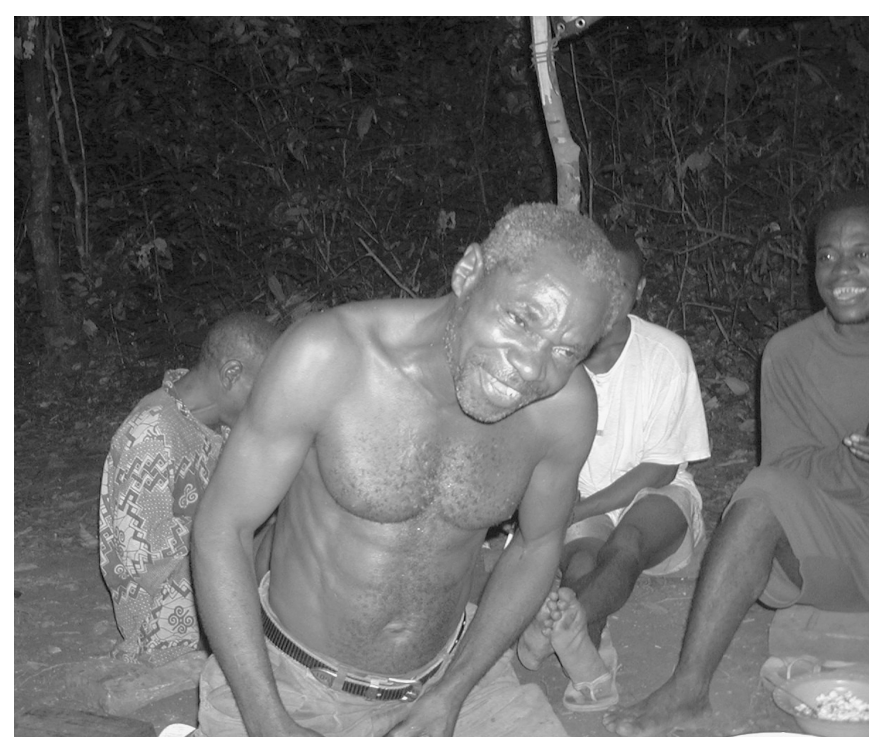

FIGURE 4. Photograph of Emile Wonga performing gano in Remis research camp (photo by Melissa Remis).
Recent reserve policy has discouraged separate BaAka camps within research camps, largely to reduce human resource use in the park. A standard infrastructure of research and tourism is emerging (Osaki and Abbaté 1995), which often integrates Baaka sleeping and eating quarters with those of other camp residents. Professionalization informs not only camp structures but also salary levels and working conditions throughout the reserve. Experienced trackers such as Emile Wonga from Messapoula (pictured in Figure 4) have become well paid for travel throughout the region, providing technical training and cultural knowledge to less-experienced trackers.

There are several important ironies here. First, these camps are built on and within the old logging infrastructure. Second, the infrastructural and interpersonal change in research camp life is occurring around an activity that is less and less likely to occur outside of core park zones: faceto-face encounters between humans and gorillas. Finally, these interactions are occurring almost exclusively among men. Although some BaAka men earn specialized status within the conservation and tourism economies, women are less and less able to spend time in the forest teaching and feeding their children in the ways described above for Mabanji's camp in the Yandoumbé sector. Instead, women are increasingly focused on agricultural labor in roadside settlements, with less meat for their children (Noss and Hewlett 2001). Hunter-gatherer families bear significant costs, as conservation converts forest use and restricts the spaces once used by entire families of hunters and gatherers largely for research and leisure by nonlocals. Finally, the conservation benefits of such policies are not yet entirely clear.

Those assessing gorilla tourism have noted that it is difficult to tease apart the various factors contributing to successful protection of gorillas, and it is easy to overestimate success when disease and military conflict can jeopardize habituated populations (Butinski and Kalina 1998; McNeilage 1995; Walsh et al. 2003). To that list of perils, we must add inexorable economic demand: On our arrival in 1997, the camp was being used intermittently by local researchers and park guards. Perhaps because of this pattern of long-term occupation by conservation-related actors, we found plentiful sign of duikers, gorillas, and elephants, despite evidence of recent hunting. Our 2002 data from areas near the town of Messapoula, and even to the park zones north of Bai Hokou, indicated very low abundance of duikers, elephants, monkeys, and apes (Remis with Malcolm and Ray in press; see also Tables 1 and 2). Long-term research on gorilla socioecology at Bai Hokou was conducted 1987-95, and since 1998.

\section{Kongana: The Intersection of Logging, Conservation, and Commercial Hunting}

In this final section, we introduce a third site, between core and buffer, within the Yandoumbé forests but inhabited increasingly by BaAka Messapoula. In addition to the BaAka camp at Kongana, there are Bilo Reserve guards stationed there. This area thus represents the frontier at 
which all the forest uses meet: research, logging, and commercialized hunting.

Hunting for meat to sell has been common at a regional scale since early colonial times, and Pygmies have long been involved in that commercial trade as it fluctuates with other commodities (Barnes 2002; Kretsinger and Hardin 2003). Today it appears to be reaching new levels of intensity and geographical extent (Eves and Ruggiero 2000; Robinson et al. 1999). Makilo, a charismatic man from Messapoula, led the BaAka camp we studied here. It was part traditional honey camp, part massive meat production camp of 32 huts (recall that Mabanji's camp in the Yandoumbé sector had only half that many). Makilo's camp also had a more intense work rhythm: Campfires burned late into the night as people wove baskets and assembled packs to carry meat from a central smoking rack to town for sale (in Mabanji's camp, families kept small individual smoking fires).

Makilo's presence as camp leader this far south relates to two key factors: (1) his labor history and (2) the rise of polygny among BaAka. Makilo, like many BaAka from further north, became familiar with the Yandoumbé sector by following the alluvial diamond industry into it, hunting to feed those seeking new sites. Those sites have since been closed by the conservation project. But in the meantime, Makilo remarried: His "Yandoumbé wife" is his second. The increase of polygyny among the BaAka in this area is likely related, as in many African contexts, to their increasing reliance on agriculture (Boserup 1989). It may also reflect new forms of wage labor and, possibly, ecological constraints caused by conservation and logging, combined with the need for more hunting territory to meet increasing commercial demand.

During our survey in 1997, human sign was less plentiful in the Kongana sector than in the Yandoumbé sector. Perhaps for that reason, chimpanzees, duikers, and elephants were more abundant (although less so than in the more protected Bai Hokou site). In 2002, overall wildlife abundance at Kongana was still higher than in other park sectors surveyed (Tables 1 and 2), perhaps because animals use its marshes during the dry season and now enjoy more guard protection there. However, where 56 gorilla nests ( 14 nest sites) had been found in 25 kilometers of transect in 1997, only nine gorilla nests (three nest sites) were found in 20 kilometers of transect in 2002 (see also Table 1). The diminished number of nests signals that the apparent general abundance of wildlife here may be a feature of site location or season and may mask trends in grave wildlife decline. The spatial heterogeneity of the 2002 data show that gorillas have been especially hard hit in areas such as Kongana, where commercial hunting has become integrated into more traditional forest camps as well as logging camps.

\section{ENTANGLED ANTHROPOLOGIES}

An overall wildlife decline relative to previous years was obvious to our 2002 research team during our survey. Wonga, the experienced tracker from Messapoula, himself remarked that in the empty buffer zone we were witnessing the last elephants as piles of decaying bones alongside smoking racks rather than the more customary piles of dung or glimpses of behemoths through the trees. Our results suggest serious consequences of multiple forest use gone unchecked. Before reflecting on the challenges faced by anthropologies of environmental change, let us review our findings with respect to the specific groups we studied on one of the last frontiers of flourishing and variously modern hunting and gathering life.

Allard Blom and colleagues (2004b) suggest possible declines in ape nest densities across the Dzanga sector at RDS from repeat surveys spanning 1997-99. Our longitudinal comparisons of Carroll's (n.d.) and Remis's dry season wildlife censuses in 2002 support this finding and further indicate a decline of elephants in the Messapoula sector (in 1985, 12.7 dung per $\mathrm{km}$; in 2002, 3.9 dung per $\mathrm{km}$ ) and to a lesser degree even in the marshy Kongana sector (in 1985, 17.9 dung per km; in 2002, 14.4 dung per km; see Carroll n.d.). Indeed, all species surveyed in 2002 were more common in park than reserve sectors, and even the core protected areas were characterized by fewer gorillas, elephants, and duikers than previous years (see Table 2). This may indicate that hunters have dispersed in search of more plentiful game and widened the scope of their target species (see Auzel and Wilkie 2000).

Our survey methods provide only a crude measure, especially of historical and very recent changes in intensity of use of any particular sector or species; we cannot definitively assess long-term changes in the exploitation of gorillas at RDS. However, the ethnography of Makilo's more commercially oriented camp (and the even larger one visited by Remis in that sector in 2002) help to explain the dramatic decline of gorillas in 2002 census data. They also suggest disturbing trends into the future. In 2004, gorilla meat was selling out in a matter of minutes at the Bayanga market; consumers competed for access to it by throwing their money on the market table (Daspit and Remis n.d.).

We have shown that the presence or absence of logging can effect game depletion. In fact, our examination confirms that mere prospecting for timber provokes dramatic changes and decreases in wildlife populations, as a result of the road networks and human traffic. The spatial patterning of gorilla sign across sectors in the 2002 census suggests that if research or tourism help to protect gorillas and elephants, the benefits may be temporary and restricted to the immediate vicinity of the permanent tourism and research camps in core sectors. By 2002, gorillas and their nests were becoming rare or absent in all sectors of the RDS exploited by humans. Yet, gorilla sign was relatively evenly distributed across sectors in 1997, and it appears that gorillas may have initially responded fairly well to selective logging and other human activities (see also White and Tutin 2001). At that time, we detected subtle variation in gorilla group sizes, nests, and feeding sign in the core and adjacent reserve and park areas at RDS. Gorillas can (and in 1997 were), like the humans 
they so often encounter, pursuing many different strategies related to the microecology and microeconomy of particular forest sectors.

Today many human reserve residents are experiencing the stark reality of decreased mobility and increased dependence on prey-poor zones; others are developing skills and careers that could not have been possible only a few years ago. These different situations illustrate fundamental contradictions regarding the interplay of social status, identity, and changing access to resources in today's tropical forests. Professionalized practices of conservation reward some actors but also relegate others-along with certain rituals and family-oriented practices-to the margins of the core areas, where they must compete with other economies and land uses. Those BaAka professionals successful in the conservation sector due to their forest-based knowledge are still shut out of the economic wealth open to some Bilo residents who, through formal education, can become the sort of "professionals" (such as civil servants and project or company managers) who control the lucrative commercial hunting of elephants, for example.

For the moment in RDS, the different activities of logging and conservation hang in balance in a "two-company town." For Yandoumbé inhabitants, logging activities create intensified, uncontrolled forest access for subsistence and commercial hunting. For those from Messapoula, conservation activities create alienation from forest access, save for specialized and largely male-dominated tourism and research practices. Both economies together, as in Kongana, enable BaAka entrepreneurs to seize short-term economic opportunity such as the bushmeat trade. Yet they risk the depletion of wildlife populations-perhaps particularly gorillas - and the decline of the remarkable variety of forest practices that we have described.

Critical analysis of new developments on the frontiers of environmental conservation-whether about popular cultures of nature conservation, environmental epidemiology, or environmental governance-could certainly proceed without engaging the sort of plodding, vinesnapping, settlement-mapping practice of collaborative anthropological fieldwork represented here. And yet, as we have shown, it would then miss clear evidence of remarkable adaptations by both animals and humans of the gendered dimensions of changing forest use and of the important cultural and ecological differences that economic activities such as logging and conservation can create within a single complex ecosystem. It might underestimate the dramatic decline of wildlife populations and the varied causes and consequences of those declines.

We believe that today's proliferating approaches to environmental anthropology can transcend accusations of being either the handmaiden to "new environmental imperialisms" or the mouthpiece of political opposition to new regimes of environmental control. Such approaches can document the specific ways in which people like the BaAka are both victims and perpetrators of contemporary environmental change and show how their responses both shape and reflect those of the animals around them. It is our hope that, in so doing, these approaches can elucidate progress made toward conservation and development goals and that, where needed, they can provide the seeds of alternative approaches. They can thus effectively explore the limits of human abilities to manage our engagements with nature. To do so, however, anthropologists from distinct traditions must be willing to confront and engage one another.

Our own collaboration has caused us each to be more cautious about the conclusions we draw from our research and to more fully consider alternate explanations-to seek more rigorous empirical data to fully document trends on the one hand and multiple historical perspectives on the other hand. It has also convinced us that anthropology remains one of the few long-term intellectual "homes" for widely divergent ways to study both human and nonhuman life. It is thus well positioned for innovation in the changing worlds of critical and scientific inquiry at present, despite its internal fault lines. We argue that such innovation comes, and always has come, not only from individual work but also from collaboration, and not only from theoretical and institutional imperatives but also from the intimacies of fieldwork.

RebecCA Hardin Department of Anthropology and School of Natural Resources and Environment, University of Michigan, Ann Arbor, MI 48109

Melissa J. Remis Department of Sociology and Anthropology, Purdue University, West Lafayette, IN 47907-1365

\section{NOTES}

Acknowledgments. The CAR government has generously granted us permission to work within the RDS reserve area since 1988. Funds and support came from World Wildlife Fund; Primate Conservation, Inc.; Purdue University; Yale University's Center for International and Area Studies; and the Harvard Academy for International and Area Studies. RDS staff provided logistical support and expertise, especially R. W. Carroll, the late U. Ngatua, A. Blom, C. Oertle, D. Renner, and C. Chiopoletta. Sylvicole logging personnel were supportive, especially C. Mpago and G. Ruchonnet. This study would not have been possible without the hard work and specialized knowledge of J. B. Kpanou, H. Zana, M. Kamo, B. Dimali, E. Terrain, B. Mbassangao, E. Ndolongbe, E. Wonga, the late P. Mokedi, and others. We thank Z. Mogba, J. Baliguini, B. Mbongo, and other colleagues at University of Bangui who facilitated our training of students and our meetings about research practices. We are grateful to the RDS residents who opened their homes, especially Mme. Gnatossia, Jacqueline, and Sahere, "Mama ti Madria." Anna Kretsinger, A. Richard, and S. Bahuchet commented on drafts of this article. Anna Kretsinger and Allard Blom contributed information from archives that assisted our efforts to create the Figure 2 map. We also thank Andrea Steves for her work to compose the maps in this article according to our specifications. We thank all of these people, acknowledging that remaining errors are our own.

1. Situated at $2^{\circ} 13^{\circ} 26^{\circ} \mathrm{N}, 16^{\circ} 11^{\circ} 26^{\circ} \mathrm{E}$, the reserve is a "buffer zone" of 340,000 hectares, surrounding the 120,000-hectare core area of national park (the total surface of the two areas is $4,200 \mathrm{~km}^{2}$ ). We refer to the ensemble of these distinct protected areas as "Réserve Dzanga Sangha" (RDS).

2. For a more complete treatment of the wildlife data, see Remis 2000 and Remis et al. n.d. Data presented here are drawn from 
our collaborative work and our respective long-term field projects. Remis field dates in the RDS include September-December 1988; August 1990-November 1992; June 1995-December 1995; JuneAugust 1997; June-August 1998; January-June 2002; and July 2005. Hardin field dates include January 1991-January 1992; July-August 1993; February 1995-March 1996; July-August 1997; and December 1999. We also draw with permission on Carroll's data from December 1984-May 1985.

3. Washburn was a "bridge builder ... of the modern synthesis of evolution in the 1940s and 1950s"; he "saw issues and problems, not disciplinary boundaries" (Zihlman 2000:61; see also Washburn 1951; Lindburg and Hamburg 1999). His contributions clearly emerged from primate fieldwork in interdisciplinary teams, such as the Asiatic Primate expedition to Borneo with Hal Coolidge in the 1930s, or that to East Africa in the 1950s.

4. See In Focus on "A New Boasian Anthropology: Theory for the 21st Century" (American Anthropologist 2004; see also Brace 2005; Pierpont 2004).

5. Remis obtained her Ph.D. in 1994; Hardin obtained her Ph.D. in 2000 .

6. Richard Carroll (1997), whose ecology work informs this study, studied wildlife at Yale's School of Forestry and Environmental Studies and was also advised by Dr. Alison Richard. He trained Remis in field ecology methods at Bai Hokou in 1988 and facilitated Hardin's work at RDS in 1991.

7. WWF is the World Wildlife Fund; GTZ is Gemeinschaft fur technische Zusammenarbeit.

8. Bahuchet summarizes the social organization of CAR's BaAka as small groups who "related by a few marriages, share the same territory, associating several times to form a large regional band" (Bahuchet 1991:247). Hart and Hall note: "Collection of most forest products by nomadic Mbuti and Efe Pygmy hunter-gatherers occurred within ten kilometers of permanent villages except for honey gathering, when small bands dispersed into remote forest areas for ... up to two months" (1996:319).

9. Bahuchet defines the term kònzà as an "owner ... also designates 'leader of a song' ... and the 'leader of a camp' (kònzà wá làngò) ... the same term characterizes the relationship between the Spirits and the Forest.... These meanings share the concept of being 'responsible for' rather than 'owning'" (1991:240; see also Lewis 2002).

10. The ntuma would lead charges during spear hunting and was a recognized expert even beyond Pygmy communities. He was a "successful hunter, expert in the subtleties of animal behavior, and possessing magical powers" (Bahuchet 1991:180, translation ours). Our field notes (July 1997) indicate that the ntuma may also have species-specific expertise, as do today's trackers for tourism or research.

\section{REFERENCES CITED}

Abel, Thomas, and John Richard Stepp

2003 A New Ecosystems Ecology for Anthropology. Conservation Ecology 7(3):12. Electronic document, http://www.consecol.org/vol7/iss3/art12, accessed January 18, 2006.

Agrawal, A.

2005 Environmentality: Technologies of Government and the Making of Subjects. Durham, NC: Duke University Press.

American Anthropologist

2004 "A New Boasian Anthropology: Theory for the 21st Century." American Anthropologist 106(3):443-494.

Auzel, Philippe, and David Wilkie

2000 Wildlife Use in Northern Congo: Hunting in a Commercial Logging Concession. In Evaluating the Sustainability of Hunting in Tropical Forests. J. Robinson and K. Redford, eds. Pp. 413-426. New York: Columbia University Press.

Bahuchet, Serge

1985 Les Pygmees Aka et la Foret Centrafricaine (BaAka Pygmies and Central African Forest). Paris: SELAF.

1991 Spatial Mobility and Access to Resources among the African Pygmies. In Mobility and Territoriality: Social and Spa- tial Boundaries among Foragers, Fishers, Pastoralists, and Peripatetics. M. J. Casimir and A. Rao, eds. Pp. 205-257. New York: Berg.

Barnes, R. F. W.

2002 The Bushmeat Boom and Bust in West and Central Africa. Oryx 36(3):236-242.

Blom, Allard, Chloe Cipolletta, Andrea Brunsting, M. H. Prins, and H. T. Harold

2004a Behavioral Responses of Gorillas to Habituation in the Dzanga-Ndoki National Park, Central African Republic. International Journal of Primatology 25(1):179-196.

Blom, Allard, R. van Zalinge, E. Mbea, I. M. A. Heitkonig, and H. H. T. Prins

2004b Human Impact on Wildlife Populations within a Protected Central African Forest. African Journal of Ecology 42:2331.

Boserup, Ester

1989 Population, the Status of Women, and Rural Development. Issue supplement, "Rural Development and Population: Institutions and Policy," Population and Development Review $15: 45-60$

Brace, C. Loring

2005 Race Is a Four-Letter Word: The Genesis of the Concept. Oxford: Oxford University Press.

Bradley, Brenda J., Diane M. Doran-Sheehy, D. Lukas, Christopher Bocsch, and Linda Vigilant

2004 Dispersed Male Networks in Western Gorillas. Current Biology 14:510-513.

Brosius, J. Peter

1999 Analyses and Interventions: Anthropological Engagements with Environmentalism. Current Anthropology 40(3):277-309.

Butinski, Thomas M., and J. Kalina

1998 Gorilla Tourism: A Critical Look. In Conservation of Biological Resources. E. J. Milner-Gulland and R. Mace, eds. Pp. 294-313. Oxford: Blackwell Science.

Carroll, Richard W.

1997 Feeding Ecology of Lowland Gorillas (Gorilla Gorilla Gorilla) in the Dzanga-Sangha Dense Forest Reserve of the Central African Republic. Ph.D. dissertation, School of Forestry, Yale University.

N.d. The Status, Distribution and Density of the Lowland Gorilla (Gorilla gorilla gorilla), Forest Elephant (Loxodonta africana cyclotis) and Associated Dense Forest Fauna in Southwestern Central African Republic: Research towards the Establishment of a Reserve for Their Protection. Unpublished MS, School of Forestry, Yale University.

Cartmill, Matt

1994 Reinventing Anthropology: American Association of Physical Anthropologists Annual Luncheon Address, April 1, 1994. Yearbook of Physical Anthropology 37:1-9.

Cavalli-Sforza, L. L.

1986 African Pygmies. New York: Academic Press.

Chapin, Mac

2004 A Challenge to Conservationists. World Watch (November-December):17-31.

Chapman, Colin, and J. E. Lambert

2000 Habitat Alteration and the Conservation of African Primates: Case Study of Kibale. American Journal of Primatology 50:169-285.

Cormier, Loretta A.

2003 Kinship with Monkeys: The Guajá Foragers of Eastern Amazonia. New York: Columbia University Press.

Daspit, Leslie, and Melissa J. Remis

N.d. Primate Conservation and the Intersection of the Bushmeat Trade. Unpublished report to World Wildlife Fund-U.S. and Purdue University, Department of Sociology and Anthropology, Purdue University.

Demesse, Lucien

1980 Techniques et Economie des Pygmees Babinga (Technologies and economy of the Bobinga Pygmies). Paris: Institut d'Ethnologie.

Doran, Diane M., and Alastaire McNeilage

1998 Gorilla Ecology and Behavior. Evolutionary Anthropology 6:120-131. 
Dove, Michael R.

2001 Interdisciplinary Borrowing in Environmental Anthropology and the Critique of Modern Science. In New Directions in Anthropology and Environment: Intersections. C. L. Crumley, ed. Pp. 90-110. Walnut Creek, CA: AltaMira Press.

Eves, Heather E., and Richard G. Ruggiero

2000 Socio-economics and the Sustainability of Hunting in the Forests of Northern Congo (Brazzaville). In Hunting for Sustainability in Tropical Forests. J. G. Robinson and E. Bennett, eds. Pp. 427-454. New York: Columbia University Press.

Fay, J. Michael

1989 Partial Completion of a Census of Gorilla Gorilla Gorilla in Southwestern Central African Republic. Mammalia 53(2):203214.

Fedigan, L. M., and Shirley C. Strum

1997 Changing Images of Primate Societies. Current Anthropology 38(4):677-681.

Fuentes, Agustin, and Linda D. Wolfe

2002 Primates Face to Face: Conservation Implications of $\mathrm{Hu}-$ man and Nonhuman Primate Interconnections, vol. 29. New York: Cambridge University Press.

Grinker, Roy Richard

1994 Houses in the Rain Forest: Ethnicity and Inequality among Farmers and Foragers in Central Africa. Berkeley: University of California Press.

Haraway, Donna

1989 Primate Visions: Gender, Race, and Nature in the World of Modern Science. New York: Routledge.

2003 The Companion Species Manifesto: Dogs, People, and Significant Otherness. Chicago: Prickly Paradigm Press.

Hardin, Rebecca

2000 Translating the Forest: Tourism, Trophy Hunting, and the Transformation of Forest Use in Southwestern Central African Republic (CAR). Ph.D. dissertation, Department of Anthropology, Yale University.

Hardin, Rebecca, with M. Remis

1997 Research and Rural Development Work Sessions: Bayanga, RCA, July 31-August 2, 1997. Report to World Wide Fund for Nature-U.S. and Central Africa Regional Program for the Environment (USAID). Electronic document, http://www.umich.edu/ infosrn/confer/CNF_SET.html, accessed March 24, 2006.

Hart, John, and Jefferson Hall

1996 Status of Eastern Zaire's Forest Parks and Reserves. Conservation Biology 10(2):316-327.

Hewlett, Barry

1991 Intimate Fathers: The Nature and Context of Aka Pygmy Paternal Infant Care. Ann Arbor: University of Michigan Press.

Joiris, Daou V.

1996 A Comparative Approach to Hunting Ritual among Baka Pygmies (Southeastern Cameroon). In Cultural Diversity among Twentieth Century Foragers: An African Perspective. S. Kent, ed. Pp. 245-275. Cambridge: Cambridge University Press.

Kano, T., and R. Asato

1994 Hunting Pressure on Chimpanzees and Gorillas in the Motaba River Area, Northeastern Congo. African Study Monographs 15(3):143-162.

Kent, Susan

1996 Cultural Diversity among Twentieth-Century Foragers: An African Perspective. New York: Cambridge University Press.

Kisliuk, Michelle

1998 Seize the Dance: BaAka Musical Life and the Ethnography of Performance. Oxford: Oxford University Press.

Kottak, Conrad P.

1999 The New Ecological Anthropology. American Anthropologist 101(1):23-35.

Kretsinger, Anna, and Rebecca Hardin

2003 Watershed, Weddings and Workforces: Migration, Sedentarization, and Social Change among the BaAka of Southwestern Central African Republic. African Studies Monographs 28:123-141.

Landau, Misia

1991 Narratives of Human Evolution. New Haven, CT: Yale University Press.
Laurance, William F., and R. O. Bierregaard Jr.

1997 Tropical Forest Fragments: Ecology, Management and Conservation of Fragmented Communities. Chicago: University of Chicago Press.

Leacock, Eleanor B., and Richard B. Lee, eds.

1982 Politics and History in Band Societies. Cambridge: Cambridge University Press.

Lee, Richard B.

1999 Science and Constructivism: Notes toward a Reconciliation. In The New Physical Anthropology: Science, Humanism, and Critical Reflection. Shirley Strum, Donald Lindberg, and David Hamburg, eds. Pp. 185-194. Upper Saddle River, NJ: Prentice Hall.

Lewis, Jerome

2002 Chimpanzees and Gorillas: Ethnic Stereotyping in the Ndoki Forest, Northern Congo-Brazzaville. Ninth International Conference on Hunting and Gathering Societies, September 2002. CHAGS 9. Electronic document, http:// www.abdn.ac.uk/chags9/1lewisJ.htm, accessed November 12, 2005.

Lindburg, Donald G., and David A. Hamburg

1999 The New Physical Anthropology: Science, Humanism, and Critical Reflection. Upper Saddle River, NJ: Prentice Hall.

Loudiyi, Dounia

1995 Census of the Population of the Dzanga Sangha Dense Forest Reserve, Southwestern Central African Republic. Washington, DC: World Wildlife Fund.

McNeilage, Alistaire

1995 Mountain Gorillas in the Virunga Volcanoes: Ecology and Carrying Capacity. Bristol, U.K.: University of Bristol.

Malcolm, Jay, and Justina C. Ray

2000 Influence of Timber Extraction Routes on Central African Small Mammal Communities, Forest Structure and Tree Diversity. Conservation Biology 14(5):1623-1638.

Noss, Andrew J.

1998 The Impacts of Cable Snare Hunting on Wildlife Populations in the Forests of the Central African Republic. Conservation Biology 12(2):390-398.

Noss, Andrew J., and Barry S. Hewlett

2001 The Contexts of Female Hunting in Central Africa. American Anthropologist 103(4):1024-1040.

Oates, John

1999 Myth and Reality in the Rain Forest: How Conservation Strategies Are Failing in West Africa. Berkeley: University of California Press.

Orlove, Ben

1980 Ecological Anthropology. Annual Review of Anthropology 9:235-273.

Osaki, John, and Mike Abbaté

1995 Tourism in Dzanga Sangha: An Interpretation and Visitor Services Plan. Washington, DC: World Wildlife Fund.

Pavelka, Mary M.

2002 Resistance to the Cross-Species Perspective in Anthropology. In Primates Face to Face: Conservation Implications of Human and Nonhuman Primate Interconnections, vol. 29. Augustin Fuentes and Linda D. Wolfe, eds. Pp. 25-44. New York: Cambridge University Press.

Peet, Richard, and Michael Watts

1996 Liberation Ecologies: Environment, Development, Social Movements. London: Routledge.

Pierpont, Claudia R.

2004 The Measure of America: How a Rebel Anthropologist Waged War on Racism. New Yorker, March 8: 48-63.

Raffles, Hugh

2002 In Amazonia: A Natural History. Princeton: Princeton University Press.

Redmond, Ian, and Eve Abe

2000 Workshop on Developing a Global Strategy for Great Ape Survival. GrASP TST Interim Report 2001-2002, Annex 3 (updated and adopted). Kinshasa, Democratic Republic of Congo: GrASP (UNEP). Electronic document, http://www.unep.org/grasp/Meetings/IGM-Kinshasa/outcomes/docs/strategy_E. pdf., accessed March 27, 2006.

Remis, Melissa J.

1993 Nesting Behavior of Lowland Gorillas in the 
Dzanga-Sangha Reserve, Central African Republic: Implications for Population Estimates and Understandings of Group Dynamics. Tropics 2(4):245-256.

1994 Feeding Ecology and Positional Behavior of Western Lowland Gorillas at Dzanga-Sangha Reserve, Central African Republic. Ph.D. dissertation, Department of Anthropology, Yale University.

1997 Western Lowland Gorillas as Seasonal Frugivores: Use of Variable Resources. American Journal of Primatology 43:87109.

2000 Preliminary Assessment of the Impacts of Human Activities on Gorillas: Gorilla Gorilla Gorilla and Other Wildlife at Dzanga-Sangha Reserve, Central African Republic. Oryx 34(1):56-65

Remis, Melissa J., J. Malcolm, and J. C. Ray

N.d. Effects of Human Disturbance on Large Mammal Populations at Dzanga-Sangha Reserve, Central African Republic. Unpublished MS.

Richard, Alison F.

1981 Changing Assumptions in Primate Ecology. American Anthropologist 83(3):517-537.

Rival, Laura M.

2002 Trekking through History: The Huaorani of Amazonian Ecuador. New York: Columbia University Press.

Robinson, John G., Kent H. Redford, and Elizabeth L. Bennett 1999 Wildlife Harvest in Logged Tropical Forests. Science 284(5414):595-596.

Robinson, John G., with M. S. Alvard, K. H. Redford, and H. Kaplan 1997 The Sustainability of Subsistence Hunting in the Neotropics. Conservation Biology 11(4):977-982.

Rodman, Peter S.

1999 Whither Primatology? The Place of Primates in Contemporary Anthropology. Annual Review of Anthropology 28:311339.

Sarno, Louis

1993 Song from the Forest: My Life among the Ba-Benjelle Pygmies. London: Bantam Press.

Sato, $\mathrm{H}$.

1992 Notes on the Distribution and Settlement Patterns of Hunter-Gatherers in Northwestern Congo. African Study Monographs 13:203-216.

Sawyer, S., and A. Agrawal

2000 Environmental Orientalisms. Cultural Critique 45:71108.

Slater, Candace, ed.

2003 In Search of the Rainforest. Durham, NC: Duke University Press.

Sponsel, Leslie E.

1997 The Human Niche in Amazonia: Explorations in Ethnoprimatology. In New World Primates: Ecology, Evolution, and Behavior. Warren G. Kinzey, ed. Pp. 143-165. New York: Aldine de Gruyter.

Spurr, David

1993 The Rhetoric of Empire. Durham, NC: Duke University Press.

Strier, Karen B.

1997 Behavioral Ecology and Conservation Biology of Primates and Other Animals. Advances in the Study of Behavior 26:101158.
Struhsaker, Thomas T.

1997 Ecology of an African Rain Forest: Logging in Kibale and the Conflict between Conservation and Exploitation. Gainesville: University Press of Florida.

Strum, Shirley C., and Linda M. Fedigan, eds.

2000 Primate Encounters. Models of Science, Gender and Society. Chicago: University of Chicago Press.

Thomas, Jacqueline, and Arom Simha

1974 Les Miimbo, Genies de la piegage rurale et le monde surnaturel des Ngbaka de la Lobaye, Republique Centrafricaine (The Mimbo, Spirits of rural trapping, and the supernatural world of the Gbaka people of the Lobaye, Central African Republic) Paris: SELAF.

Tsing, Anna L.

2004 Friction: An Ethnography of Global Connection. Princeton: Princeton University Press.

Tutin, Carolyn E. G., and M. Fernandez

1984 Nationwide Census of Gorilla (G. g. gorilla) and Chimpanzee (Pan t. troglodytes) Populations in Gabon. American Journal of Primatology 6:313-336.

Van Schaik, C. P., K. A. Monk, and J. M. Yarrow Robertson

2001 Dramatic Decline in Orangutan Numbers in the Leuser Ecosystem. Oryx 35(1):14-25.

Wallis Jannette, Lee D. R.

1999 Primate Conservation: The Prevention of Disease Transmission. International Journal of Primatology 20(6):803826.

Walsh, Peter, K. A. Abernathy, M. Bermejo, R. Beyers, P. DeWachter, M. E. Akou, B. Huijbergts, D. Idiata, A. Kandem Tokam, A. M. Kilbourn, S. A. Lahm, S. Latour, F. Maisels, C. Mbina, Y. Mihindou, S. Ndong Obiang, E. Ntsame Etta, M. Starkey, P. Telfer, M. Thibault, C. E. G. Tutin, L. J. T. White, and D. S. Wilkie

2003 Catastrophic Ape Decline in Western Equatorial Africa. Nature 422(6932):611-614.

Washburn, Sherwood. L.

1951 The New Physical Anthropology. Transactions of the New York Academy of Sciences, Series 2, 13(7):298-304.

Weiss, R. A., and Richard W. Wrangham

1999 From Pan to Pandemic. Nature 397(6718):385-386.

Wheatley, Bruce Panton

1999 The Sacred Monkeys of Bali. Prospect Heights, IL: Waveland Press.

White, Lee G. T., and Caroline E. G. Tutin

2001 Why Chimpanzees and Gorillas Respond Differently to Logging: A Cautionary Tale from Gabon. In African Rain Forest Ecology and Conservation. W. Weber, L. J. T. White, A. Vedder, and L. Naughton-Treves, eds. Pp. 449-462. New Haven, CT: Yale University Press.

White, Lee G. T., with A. Edwards

2000 Conservation Research in African Rain Forests: A Technical World Wildlife Fund N.D. Unpublished, MS, Census of the RDS-Bayanga area, 2001. Handbook. New York: Wildlife Conservation Society.

World Wildlife Fund

N.d. Unpublished MS, Census of the RDS-Bayanga area, 2001.

Zihlman, Adrienne L.

2000 A Skeletal Survey of Physical Anthropology in the U.S. Rivista di Antropologia (Roma) 78:57-66. 